\title{
PEMODELAN DAN SIMULASI PV-INVERTER TERINTEGRASI KE GRID DENGAN KONTROL ARUS "RAMP COMPARISON OF CURRENT CONTROL”
}

\author{
Hazlif Nazif, Muh. Imran Hamid \\ Jurusan Teknik Elektro, Fakultas Teknik, Universitas Andalas \\ Email: hazlif_n@yahoo.co.id
}

\begin{abstract}
Abstrak- Dalam paper ini, operasi pengontrolan arus tipe ramp comparison current control dianalisis dan disimulasikan pada sebuah inverter pembangkit listrik tenaga surya tipe terhubung ke grid. Model simulasi dibangun menggunakan perangkat lunak MATLAB/SIMULINK. Kinerja perangkat keras dievaluasi dan dianalisis dengan melihat dan membandingkan hasil simulasi dan hasil teoritis terhadap parameter input PLTS yaitu temperatur dan irradians. Simulasi menunjukkan kesamaan antar hasil yang diperoleh dan hasil secara teoritis. Performa kontrol arus ramp comparison current control dievaluasi dengan memvariasikan frekuensi dan amplitude gelombang segitiga sebagai sinyal pemodulasi kontrol arus ramp. Untuk setiap frekuensi dan amplitudo tersebut, kualitas arus keluaran dianalisis dengan melihat distorsi arus yang dihasilkan. Simulasi menunjukkan untuk frekuensi gelombang segitiga sebesar $1250 \mathrm{~Hz}$, diperoleh THD arus sebesar 7,25\%, sementara untuk frekuensi 4950 Hertz, THD yang diperoleh adalah sebesar $4.10 \%$. Nilai-nilai ini menunjukkan bahwa semakin besar frekuensi gelombang segitiga yang diterapkan, maka kualitas arus yang dihasilkan semakin baik (rendah distorsi). Sementara itu, pengaruh amplitude gelombang segitiga menunjukkan semakin tinggi amplitudo gelombang segitiga semakin buruk kualitas daya arus output yang diperoleh, untuk amplitudo gelombang sebesar 15 Volt pada frekwensi gelombang $4950 \mathrm{~Hz}$, THD arus yang dihasilkan adalah sebesar $4.10 \%$, sementara untuk amplitudo sebesar 20 Volt, THD arus yang dihasilkan adalah sebesar 4,31\%.
\end{abstract}

Kata kunci: PV-Inverter, MATLAB, THD, Kontrol Arus Ramp Comparison Current Control dan Grid

\begin{abstract}
In this study, the operation of the ramp comparison current control is analyzed and simulated on a grid connected inverter used in a photovoltaic power plant. The model of the photovoltaic power plant is built using MATLAB / SIMULINK. Performance of the hardware are evaluated and analyzed by comparing the simulation and the theoretical results due to input parameter of the photovoltaic plant, i.e. temperature and irradiation. Simulations results showed the similarity with the theoretical results. Performances of the current control were evaluated by varying the amplitude and frequency of triangle wave as the modulation signal. For each frequency and the amplitude, the quality of the output current is analyzed by reviewing the generated current distortion. Simulation shows that for the triangle wave frequency of $1250 \mathrm{~Hz}$, it was produced the current THD of 7.25\%, while for the frequency $4950 \mathrm{Hertz}$, current THD obtained was $4.10 \%$. These values indicate that the larger the triangle wave frequency was applied, the better the quality of the resulting current (low distortion). While, the effect of the triangle wave amplitude indicates that the higher the triangle wave's amplitude, the poorer the quality of output currents would be obtained, for an amplitude of 15 Volts and frequency of $4950 \mathrm{~Hz}$, the generated THD current was $4.10 \%$, while for the amplitude of 20 Volts, the generated THD current was $4.31 \%$.
\end{abstract}

Keywords: PV-Inverter, MATLAB, THD, Ramp Comparison Current Control and Grid

\section{PENDAhuluan}

Pemanfaatan sumber energi terbarukan yang dipergunakan semakin meningkat dengan mengurangi ketergantungan pada penggunaan energi fosil makin menipis dalam mendukung program pengembangan energi terbarukan (EBT) [1]. Di Indonesia penggunaan energi fosil, seperti BBM dan batubara masih berada pada rating teratas sebagai sumber energi primer pada pembangkit listrik. Dewan Energi Nasional (DEN) telah menskenariokan, pada tahun 2025 pemanfaatan EBT di Indonesia menjadi berimbang dengan penggunan energi fosil. Penggunaan energi EBT dari $5.7 \%$ diharapkan meningkat hingga $25.9 \%$ pada tahun 2025 seperti diperlihatkan oleh gambar 1 [2].

Berdasarkan statistik PLN 2013 [3], pelanggan terbesar dari energi listrik yang 
dikelola PT.PLN adalah sektor rumah tangga, dengan persentase mencapai $41.17 \%$ dari seluruh energi listrik yang disediakan oleh PLN dengan jumlah pelanggan $92.81 \%$ dari keseluruhan jumlah pelanggan PLN (gambar 2). Hal ini artinya PLN masih mengunakan energi fosil pada sektor rumah tangga dan ketersediaan bahan bakar untuk pengoperasian sumber listrik dari fosil sudah sangat terbatas.

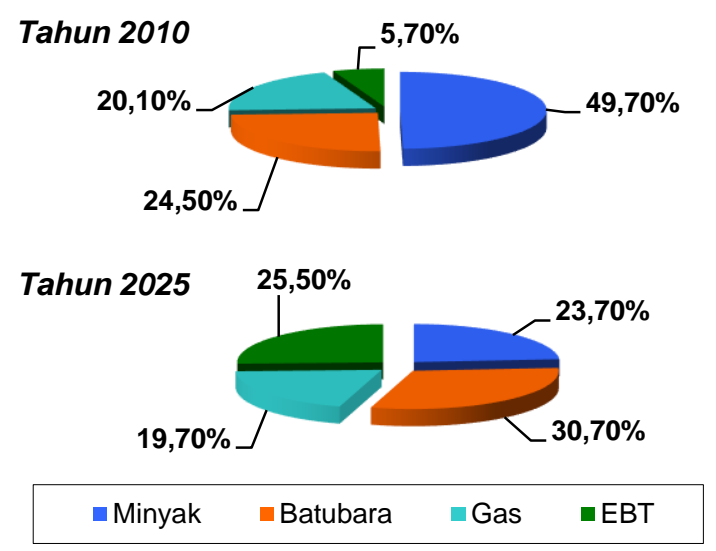

Gambar 1. Bauran Sumber Energi Kelistrikan Indonesia [4].

Untuk mengatasi permasalahan diatas maka diperlukan pembangkit tenaga listrik alternatif lain berupa sumber energi terbarukan seperti photovoltaic (PV). Sumber PV merupakan sumber energi terbarukan yang cukup popular yang bersih dan tersedia secara bebas dapat dijadikan sebagai alternatif yang fleksibel [1].

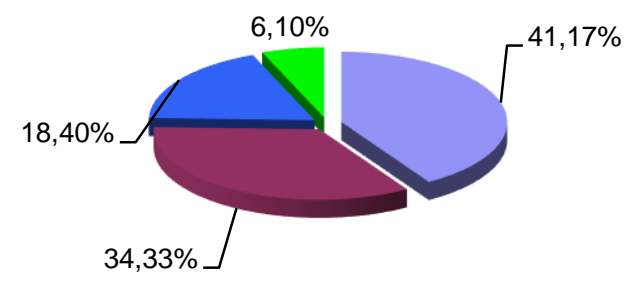

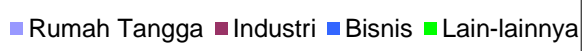

Gambar 2. Jumlah Energi Terjual Per Jenis Pelanggan [3]

Sistem PLTS terdiri dari beberapa jenis, diantaranya Stand alone photovoltaic dan Grid connected photovoltaic System. Stand alone photovoltaic (PLTS secara off grid) adalah sistem pembangkit listrik PV terpusat (PLTS terpusat) merupakan sistem pembangkit mandiri. Sistem ini hanya mengandalkan energi matahari sebagai satu-satunya sumber energi utama dengan menggunakan rangkaian modul PV untuk menghasilkan energi listrik sesuai dengan kebutuhan, sedangkan Grid connected photovoltaic System (Pembangkit listrik tenaga PV tersambung ke grid ) merupakan PLTS yang tersambung secara langsung ke grid [4]. Adapun keuntungan sistem PLTS terintegrasi ke grid adalah sebagai berikut [4]:

- Mereduksi penggunaan bahan bakar fosil sehingga mengurangi polusi/emisi bahan bakar.

- Bersih, tidak berisik, menggunakan energi gratis dari matahari sepanjang tahun.

- Tidak memerlukan biaya operasional sepeserpun.

- Pengoperasian dan perawatan sistem yang sangat mudah.

- Membantu menstabilkan tegangan PLN pada sisi beban.

- Membantu mengurangi biaya tagihan listrik bulanan.

- Meningkatkan nilai prestise pada rumah/perkantoran.

- Kelebihan Listrik yang dihasilkan PV dapat dijual kepada PLN (tergantung kebijakan).

Sistem PLTS terdiri dari komponen modul PV dan konverter listrik dan sistem kontrol operasi maupun kontrol optimasi ekstraksi daya (MPPT). Strategi kontrol arus pada inverter dapat berupa kontrol hysteresis, prediktif kontrol dan kontrol arus ramp comparison current control dan jenis kontrol arus lainnya. Kontrol hysteresis adalah kontrol yang membandingkan arus output dengan arus referensi setelah diberi batas toleransi yang telah ditentukan, kontrol prediktif adalah menghitung tegangan inverter yang dibutuhkan untuk memaksa arus mengikuti arus referensi pada sampel waktu tertentu, sedangkan kontrol ramp comparison current control adalah kontrol yang membandingkan arus error ke dalam gelombang segitiga untuk menghasilkan sinyal penyulutan yang digunakan untuk mengendalikan saklar statis pada inverter dari sistem PLTS [5] [7].

Pada paper ini, dikaji pengunaan metode kontrol arus ramp comparison current control untuk inverter satu fasa yang terhubung ke jaringan grid. Metode ini mempunyai respon dinamik yang cepat dan frekuensi switching yang konstan dalam mengendalikan arus output dari inverter [8]. Kontrol arus ini mampu 
merespon perubahan pada sumber energi maupun grid dengan cepat dan harmonisa yang dihasilkan adalah dari jenis predictable harmonisa sehingga mudah diproteksi [7].

Untuk melakukan kajian penerapan sistem kontrol, diperlukan model yang mewakili sistem PV-Inverter terhubung dengan grid, juga diperlukan simulasi yang dapat menggambarkan mekanisme kerja sistem kontrol arus ini pada sistem PV-Inverter terhubung dengan grid.

\section{TINJAUAN PUSTAKA}

\subsection{Photovoltaic (PV)}

Sel surya atau photovoltaic (PV) dapat berupa alat semikonduktor penghantar aliran listrik yang dapat mengubah energi surya secara langsung menjadi bentuk tenaga listrik secara efisien. Sel surya disusun membentuk sebuah sel $P V$ dengan kapasitas dan tegangan tertentu. Untuk mendapatkan daya yang besar, maka sejumlah sel dihubungkan secara seri dan paralel sebagai suatu panel atau modul PV. Selanjutnya, gabungan beberapa modul yang terhubungan secara seri, paralel atau kombinasi keduanya disebut array (Gambar 3).

Karakteristik I-V dari sel PV dapat dilihat dari kurva I-V pada gambar 4. Pada kurva tersebut terdiri atas arus hubung singkat $\left(\mathrm{I}_{\mathrm{sc}}\right)$, tegangan rangkaian terbuka $\left(\mathrm{V}_{\mathrm{oc}}\right)$ dan operasi titik daya maksimum atau yang biasa dikenal dengan maximum power point atau disingkat menjadi MPP.

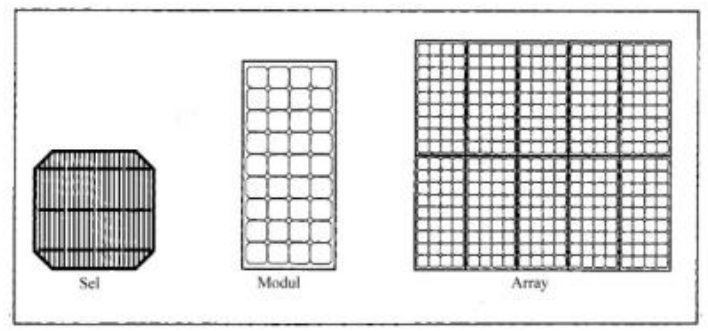

Gambar 3. Beberapa sel PV membentuk modul dan beberapa modul membentuk array

Sesuai model rangkaian ekivalen sel surya sebagaimana Gambar 5, hubungan arus keluaran suatu sel PV ditulis dengan:

$$
I_{p v}=I_{L}-I_{0}\left[e^{q\left(\frac{V+I R_{S}}{n k T}\right)}-1\right]-\left(\frac{V+I . R_{S}}{R_{P}}\right)
$$

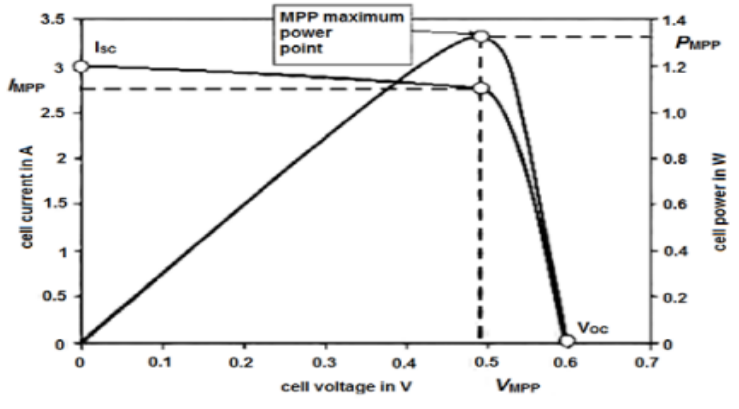

Gambar 4. Kurva karakterisktik I-V dan P-V pada sel PV.

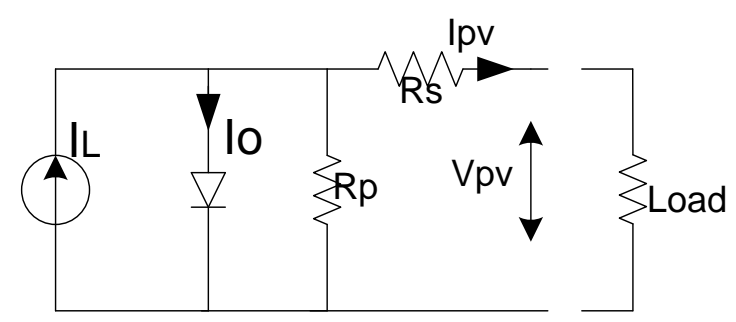

Gambar 5. Rangkain ekivalen sel PV [9]

Dimana:

$\mathrm{I}_{\mathrm{L}}=$ Arus sel PV (A)

$\mathrm{V}=$ Tegangan sel $\mathrm{PV}(\mathrm{V})$

$\mathrm{I}_{\mathrm{pv}}=$ Arus yang dihasilkan oleh sel PV (A)

$\mathrm{I}_{0}=$ Arus satrurasi reverse (A)

Isc $=$ Arus hubung singkat $(\mathrm{A})$

$\mathrm{n}=$ Faktor ideal dioda (bernilai 1 untuk dioda ideal)

$\mathrm{q}=$ Pengisian elektron $\left(1,602 \times 10^{-19} \mathrm{C}\right)$

$\mathrm{k}=$ Konstanta boltzman $\left(1,3806 \times 10^{-23} \mathrm{~J} \mathrm{~K}^{-1}\right)$

$\mathrm{T}=$ Temperatur sel PV $(\mathrm{K})$

$\mathrm{T}_{1}=$ Temperatur referensi sel $\mathrm{PV}\left(298^{\circ} \mathrm{K}\right)$

Rs $=$ Hambatan $\operatorname{seri}(\Omega)$

$\mathrm{Rp}=$ Hambatan paralel $(\Omega)$

$\mathrm{K}_{\mathrm{O}}=$ Koefisien temperatur arus $\left(\% /{ }^{\circ} \mathrm{K}\right)$

\subsection{Maximum Power Point Tracking}

Karakteristik daya keluaran sel PV bervariasi dan sangat dipengaruhi oleh perubahan radiasi sinar matahari dan temperatur permukaan sel PV, akibatnya, letak titik MPP modul akan selalu berubah. Untuk itu diperlukan sebuah algoritma MPPT. Maximum Power Point Tracker adalah sebuah fungsi/algorithma yang ditujukan untuk mencari maximum power point (MPP) sesuai dengan MPP dari kurva karakteristik P-V pada panel PV[10]. MPPT menemukan MPP sehingga dapat memaksimalkan daya yang diekstrak dari 
sumber energi PV. Beberapa algorithma MPPT adalah Perturb and Observe, Incremental Conductance, Dynamic Approach, Temperature Methods dan algorithma lainnya.

Pada penelitian ini, metode yang digunakan adalah Incremental Conductance (INC). Pencarian MPP dilakukan dengan cara menggunakan persamaan $\Delta I / \Delta V$ modul.

$$
\begin{aligned}
& \frac{d P}{d V}=0 \\
& \frac{d P}{d V}=\frac{d(I . V)}{d V}=I+V \frac{d I}{d V}=0 \\
& I+V \frac{d I}{d V} \cong I+V \frac{d I}{d V}=0 \\
& \frac{\Delta I}{\Delta V}=-\frac{I}{V}
\end{aligned}
$$

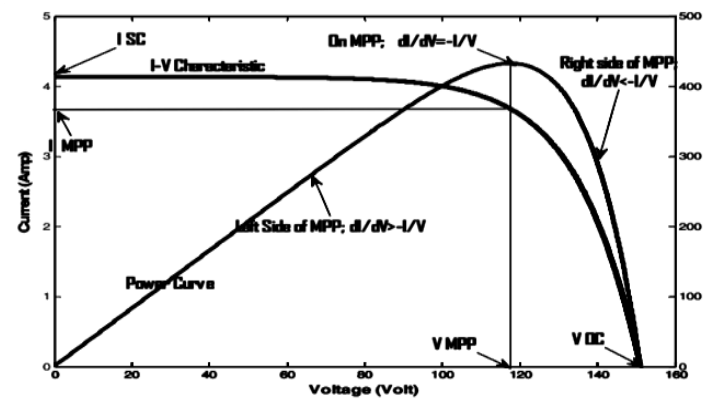

Gambar 6. Posisi $\Delta \mathrm{I} / \Delta \mathrm{V}$ yang berbeda pada kurva daya panel PV [7]

Pada titik daya maksimum (MPP), nilai $\Delta I / \Delta V$ dari incremental conductance adalah $-I / V$, sementara pada lokasi lainnya nilainya bervariasi, yaitu [6]:

$\frac{\Delta I}{\Delta V}=-\frac{I}{V}$ daya maksimal terdapat pada sisi tengah MPP

$\frac{\Delta I}{\Delta V}>-\frac{I}{V}$ daya maksimal terdapat pada sisi kiri MPP

$\frac{\Delta I}{\Delta V}<-\frac{I}{V}$ daya maksimal terdapat pada sisi kanan MPP

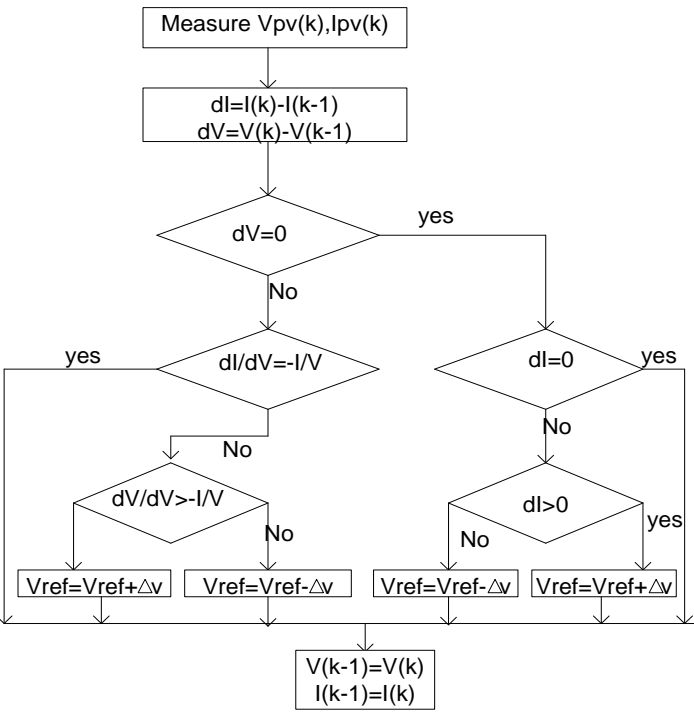

Gambar 7. Flowchart dari metode INC[6]

\subsection{Konverter boost}

Konverter boost digunakan untuk menaikkan tegangan DC yang rendah. Gambar 8, menggambarkan skema sederhana sebuah konverter boost. Skema ini terdiri dari sumber tegangan input $\left(\mathrm{V}_{\mathrm{S}}\right)$, induktor ( $\left.\mathrm{L}\right)$, saklar $(\mathrm{S})$, dioda (D), kapasitor filter (C), dan resistensi beban $(\mathrm{R})$.

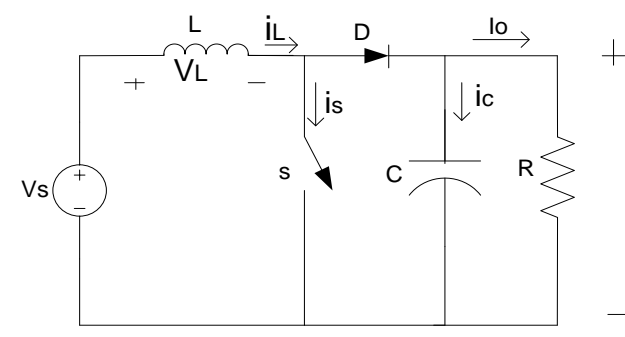

Gambar 8. Skema rangkaian konverter boost

\subsection{Inverter}

Inverter adalah suatu rangkaian yang berfungsi untuk mengubah tegangan masukan arus searah (DC) menjadi tegangan keluaran arus bolak balik (AC). Tegangan dan frekuensinya dapat diatur sesuai dengan yang diinginkan. Pengaturan tegangan inverter yang umum digunakan adalah dengan metode Modulasi Lebar Pulsa (Pulse Width Modulation, PWM). Inverter yang diatur dengan metode ini selanjutnya disebut inverter PWM. 


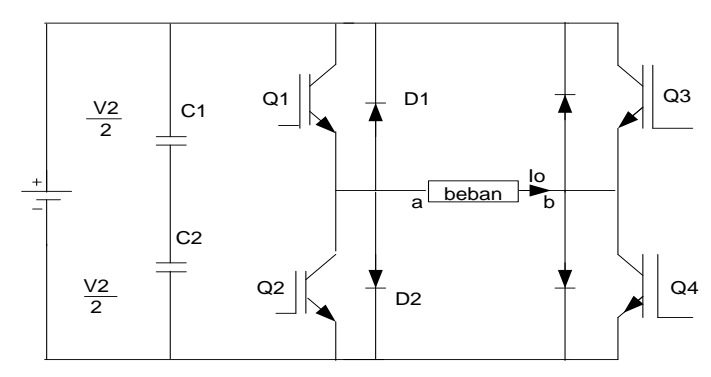

Gambar 9. Rangkaian inverter 1 fasa jembatan penuh

\subsection{Kontrol arus ramp comparison current control}

Kontrol arus ramp comparison current control diwujudkan dengan menambahkan sinyal gelombang sinusoidal ke sebuah sinyal segitiga (triangular wave) untuk membuat sebuah sinyal referensi segitiga yang mengikuti pola sinusoidal. Sinyal ini kemudian dibandingkan dengan arus aktual dari inverter. Titik dimana gelombang sinusoidal segitiga dan arus aktual bersilangan menjadi waktu komponen switch inverter diaktifkan (ON). Jika arus aktual lebih besar daripada sinusoidalsegitiga, komponen switch inverter dimatikan(OFF) dan sebaliknya jika arus aktual kurang dari sinusoidal-segitiga maka komponen switch inverter diaktifkan lagi (ON). Bentuk gelombang arus keluaran pada inverter dengan metode kontrol arus ramp comparison of current control, dapat dilihat pada gambar 10 [7][11].

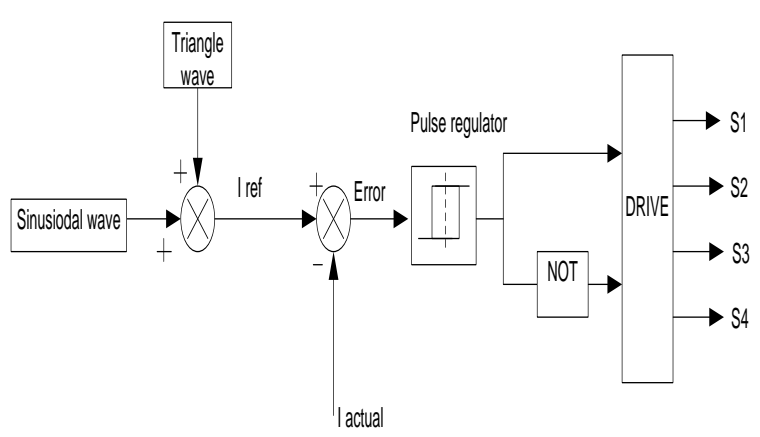

(a)

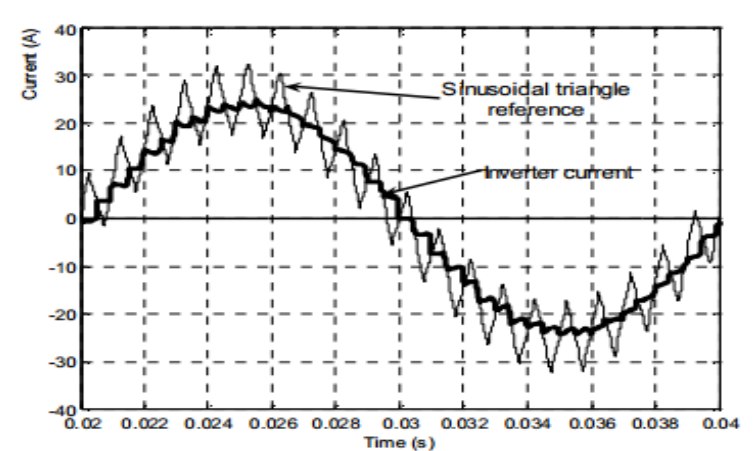

(b)

Gambar 10. (a) Model kontrol arus ramp comparison of current control dan (b) Bentuk gelombang keluaran berupa sinusoidal segitiga referensi yang dihasilkan oleh kontrol arus ramp comparison of current control [7][11].

\subsection{Phase locked loop}

Pada sistem PV-Inverter terhubung dengan grid, tujuan dari Phase locked loop (PLL) adalah untuk menyinkronkan sudut fasa sesaat dari tegangan inverter $\left(\theta_{\text {inv }}\right)$ dengan sudut fasa dari tegangan grid $\left(\theta_{\text {grid }}\right)$ untuk digunakan dalam pengendalian inverter [12]. Gambar 11 menunjukkan diagram blok dari inverter terhubung dengan grid yang menggunakan PLL sebagai sebuah metode sinkronisasi.

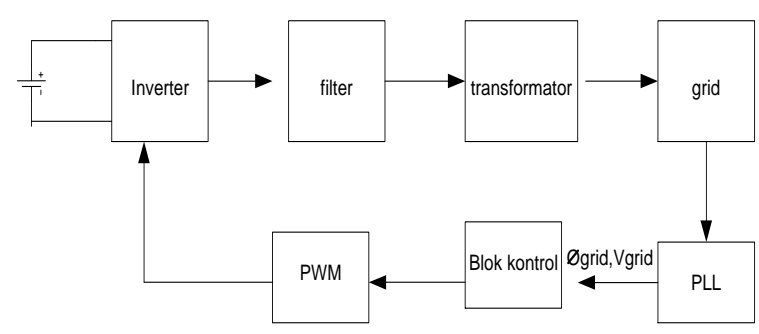

Gambar 11. Inverter terhubung ke grid dengan sebuah PLL berdasarkan metode sinkronisasi

[12].

Struktur dasar dari sebuah PLL ditunjukkan pada gambar 12, di mana perbedaan antara sudut fasa dari input dan bahwa sinyal output diukur oleh detector phase (PD) dan melewati Loop Filter (LF), yang bertindak sebagai sistem kontrol dalam loop. Sinyal output LF drive Voltage-Controlled Oscillator (VCO), yang menghasilkan output sinyal, yang akan mengikuti sinyal input. 


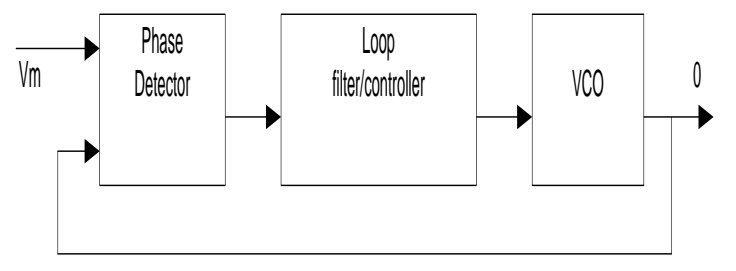

Gambar 12. Struktur PLL loop tertutup [12]

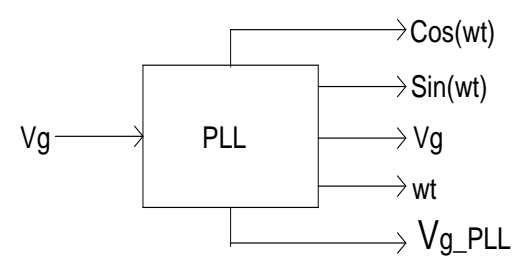

Gambar 13. Model PLL

\subsection{Distorsi Harmonisa}

Pada kondisi ideal, gelombang arus maupun tegangan seharusnya hanya memiliki satu frekuensi dasar. Gelombangnya dikatakan memiliki harmonisa jika pada gelombang tersebut terdapat sinyal dengan frekuensi berbeda dengan frekuensi fundamentalnya. Parameter yang digunakan untuk mengetahui kandungan harmonisa dikenal dengan istilah total harmonic distortion (THD). Terdapat dua jenis parameter THD, THD $\mathrm{v}$ untuk tegangan dan THDi untuk arus. Kedua parameter tersebut dapat dihitung dengan menggunakan persamaan di bawah ini.

$$
\begin{aligned}
& T H D v=\frac{\sqrt{\sum_{n=2}^{N} V_{n}^{2}}}{V_{1}} \times 100 \% \\
& T H D i=\frac{\sqrt{\sum_{n=2}^{N} i_{n}^{2}}}{V i_{1}} \times 100 \%
\end{aligned}
$$

Nilai THD biasanya dinyatakan dalam persen. Ketika nilainya cukup besar, risiko peralatan mengalami kerusakan semakin besar pula. Terdapat batasan nilai THD untuk tegangan maupun arus yang diizinkan. Untuk sistem dengan tegangan di bawah $69 \mathrm{kV}$, IEEE 519 memberi batasan sebesar $3 \%$ untuk individual harmonik dan $5 \%$ untuk total harmonic distortion-nya. Semakin besar tegangan suatu sistem, batasan distorsi harmonik yang diperbolehkan pun semakin kecil [13].

\subsection{Strategi kontrol arus pada inverter PV- Inverter terhubung dengan grid.}

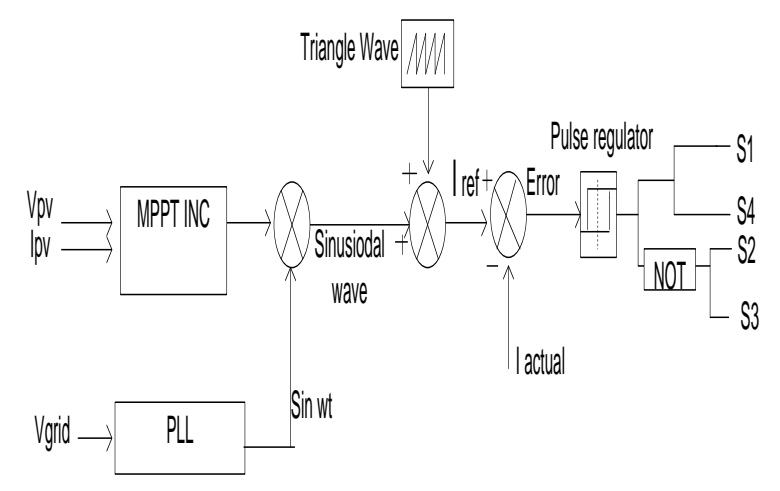

Gambar14. Sistem kontrol arus pada inverter PV terhubung dengan grid.

Gambar 14 menunjukkan kontrol arus ramp comparsion current control pada PV-inverter yang dilengkapi dengan mekanisme MPPT. Nilai Vpv dan Ipv merupakan input bagi blok fungsi MPPT. MPPT selanjutnya menghasilkan arus referensi awal Im. Perkalian besarnya Im dengan fasa ( $\sin w t)$ menghasilkan sinyal gelombang referensi (Iref). Sudut sinkronisasi grid $(\Theta=w t)$ yang diperoleh dari blok PLL digunakan untuk menghasilkan nilai vektor tegangan grid dengan besar satu perunit [14]:

$$
V=\operatorname{Sin} \omega t
$$

Selanjutnya menggunakan sinyal PLL, nilai arus sesaat, arus referensi dapat dihitung dengan mengunakan rumus sebagai berikut.

$$
\text { Iref }=\mathbf{I m} \cdot \sin \omega t
$$

Arus gelombang referensi (Iref) selanjutnya dibandingkan dengan arus aktual dari inverter sehingga menghasilkan arus error. Sinyal arus error dimasukkan ke dalam pengatur pulsa untuk membuat pola penyulutan komponen swich inverter.

\section{METODOLOGI PENELITIAN}

\subsection{Pemodelan PV array}

Model PV array yang terdiri dari tiga modul tersusun seri terlihat pada gambar 16. Dalam pemodelan ini, datasheet dari modul NE80E2E digunakan sebagai acuan. Karakteristik modul tersebut, dapat dilihat pada tabel 1 . 
Tabel 1. Spesifikasi SHARP NE80E2E

\begin{tabular}{|l|l|}
\hline \multicolumn{1}{|c|}{ Cell } & \multicolumn{1}{|c|}{$\begin{array}{c}\text { Polycrystalline } \\
\text { silicon solar cells }\end{array}$} \\
\hline $\begin{array}{l}\text { No.of cell and } \\
\text { connections }\end{array}$ & 36 in series \\
\hline Application & DC 12 V system \\
\hline Maximum system voltage & DC 540 V \\
\hline Series fuse rating & $10 \mathrm{~A}$ \\
\hline Dimensions & $1.200 \times 530 \times 35 \mathrm{~mm}$ \\
\hline Nominal power & $80 \mathrm{~W}$ \\
\hline Weight & $8.5 \mathrm{~kg}$ \\
\hline Type of ouput terminal & $\begin{array}{l}\text { Lead wire with } \\
\text { connector }\end{array}$ \\
\hline
\end{tabular}

Tabel 2. Karakteristik optikal elektro SHARP NE80E2E

\begin{tabular}{|l|c|c|c|c|}
\hline Parameters & Symbol & Minimal & Type & Unit \\
\hline $\begin{array}{l}\text { Open circuit } \\
\text { voltage }\end{array}$ & Voc & - & 21.3 & $\mathrm{~V}$ \\
\hline $\begin{array}{l}\text { Maximum } \\
\text { power } \\
\text { voltage }\end{array}$ & Vpm & - & 17.1 & $\mathrm{~V}$ \\
\hline $\begin{array}{l}\text { Short cicuit } \\
\text { current }\end{array}$ & Isc & - & 5.31 & $\mathrm{~A}$ \\
\hline $\begin{array}{l}\text { Maximum } \\
\text { power }\end{array}$ & $\mathrm{Ipm}$ & 76.0 & 80.0 & $\mathrm{~W}$ \\
\hline $\begin{array}{l}\text { Temperature } \\
\text { coefficients } \\
\text { of P }\end{array}$ & \multicolumn{3}{|l|}{$-0.485 \% /{ }^{\circ} \mathrm{C}$} \\
\hline $\begin{array}{l}\text { Temperature } \\
\text { coefficients } \\
\text { of ISC }\end{array}$ & \multicolumn{4}{|l|}{$+0.053 \% /{ }^{\circ} \mathrm{C}$} \\
\hline $\begin{array}{l}\text { Temperature } \\
\text { coefficients } \\
\text { of } \mathrm{V}_{\mathrm{OC}}\end{array}$ & \multicolumn{4}{|l}{$-78,1 \mathrm{mV} /{ }^{\circ} \mathrm{C}$} \\
\hline
\end{tabular}

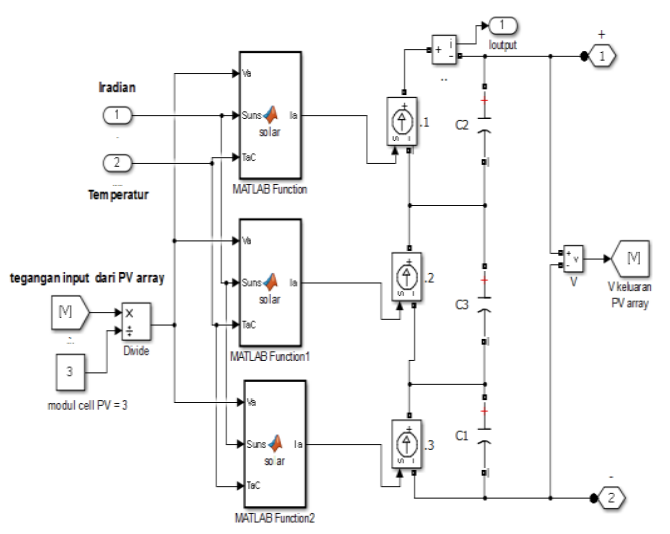

Gambar 15. Model PV array

\subsection{Model MPPT}

Algorithma MPPT yang digunakan adalah metode Incemental Conductance, dibuat dengan mengunakan kode program MATLAB [15].
Model MPPT ini mempunyai input berupa $\mathrm{V}$ dan I dari PV array; Vpv dan Ipv. Blok memori ditambahkan pada blok MPPT sehingga nilai $\Delta \mathrm{I} / \Delta \mathrm{V}$ dapat dihitung. Output dari MPPT berupa sinyal referensi selanjutnya diumpankan ke blok kontrol arus.

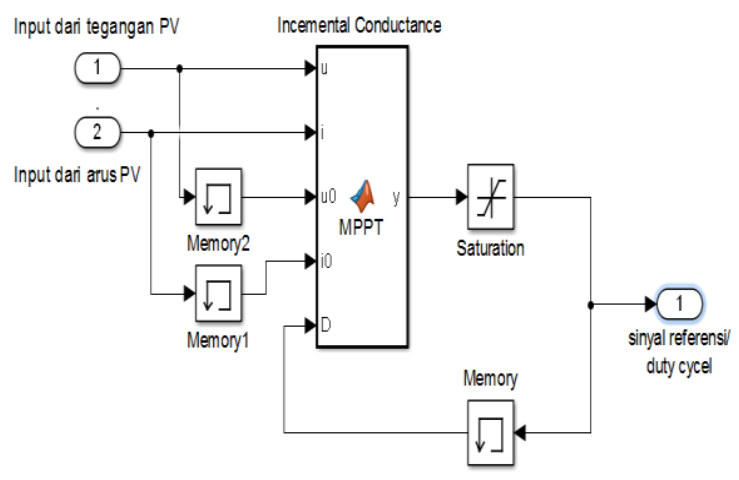

Gambar 16. Model algorithma MPPT dengan metode incremental conductance

\subsection{Model Kontrol arus ramp comparison of current control}

Gambar 17 menunjukkan model simulasi kontrol arus ramp comparison of current control. Input dari blok in adalah sinyal referensidari Blok MPPT dan gelombang segi tiga dengan frekuensi tertentu. Sedangkan outputnya merupakan sinyal gate bagi komponen switch inverter.

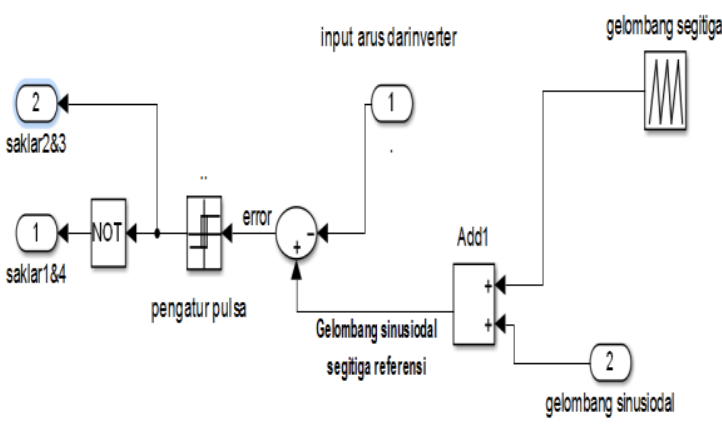

Gambar 17. Model kontrol arus ramp comparison of current control

\subsection{Model PV-Inverter terhubung dengan grid}

Gambar 18 menunjukkan model lengkap rangkaian simulasi yang digunakan dalam paper ini. 


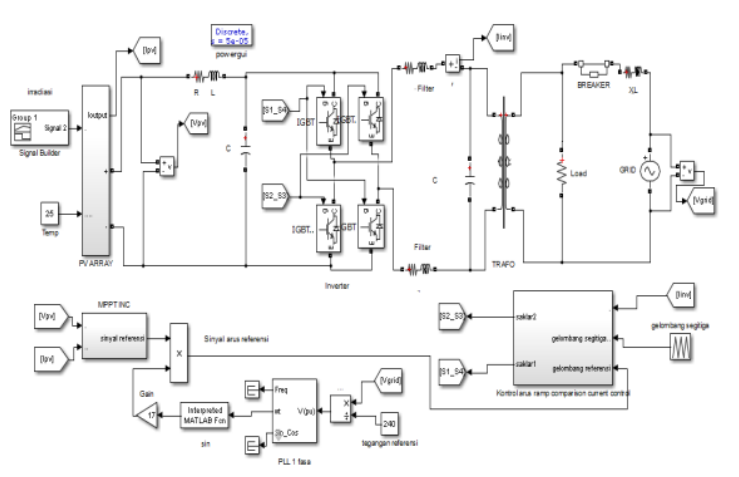

Gambar 18. Simulasi sistem PV-Inverter terintegrasi ke grid dengan kontrol arus ramp comparison of current control mengunakan

\section{PLL}

\section{HASIL DAN PEMBAHASAN}

\subsection{PV array}

Pengujian dilakukan pada model dalam kondisi irradiansi $1000 \mathrm{~W} / \mathrm{m}^{2}$ dengan temperatur panel PV $25^{\circ} \mathrm{C}$, dengan menghubungkan PV dengan beban yang bervariasi antara $0-1000 \Omega$. Hasil pengujian diperlihatkan pada gambar 19. Daya maksimum Pmp sekitar 243,7 Watt diperoleh pada saat tegangan Imp sekitar 50,83 Volt dengan arus Imp 4,795 A.

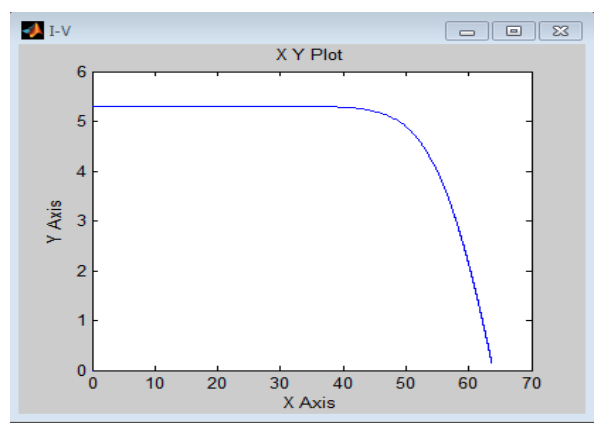

(a)

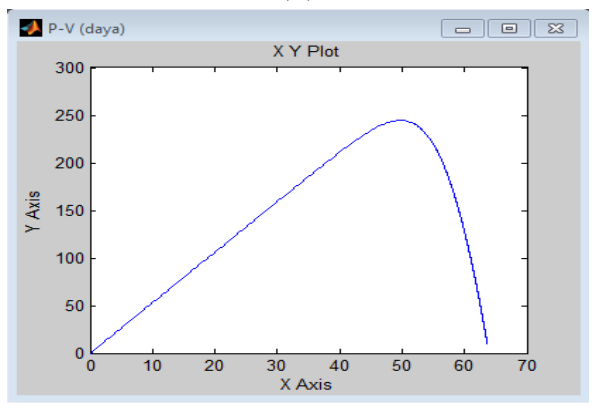

(b)

Gambar 19. Pada PV array, (a)Kurva karakteristik I-V, (b)Kurva karakteristik P-V

\subsection{Rangkaian Algoritma MPPT dengan metode Incremental Conductance (INC) Pengujian dilakukan untuk melihat} bagaimana kemampuan algoritma MPPT mencapai MPP sesuai dengan karakteristik PV array yang diinginkan. Dari hasil pengujian model terlihat bahwa perubahan tingkat besaran iradiansi dan temperatur menyebabkan perubahan pada keluaran MPPT, Hal ini menunjukkan berfungsinya algorithma MPPT yang diterapkan.

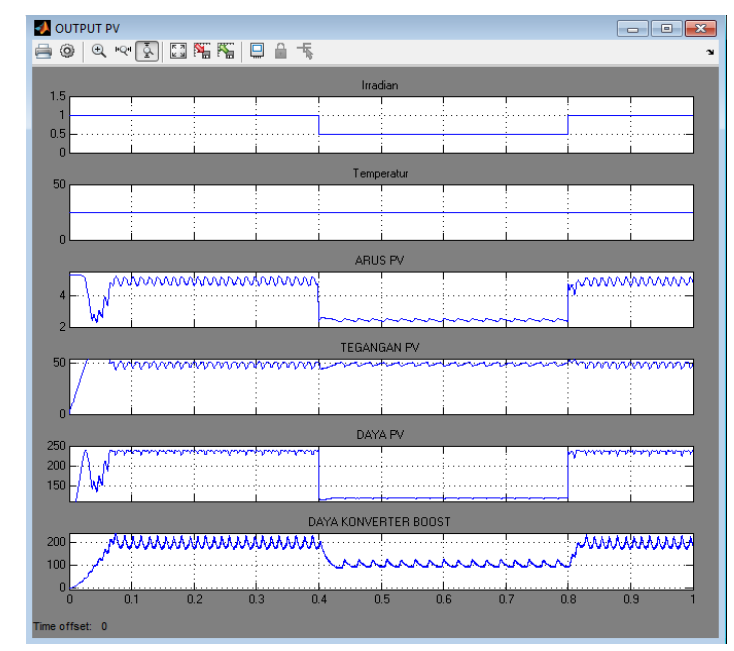

Gambar 20. Gelombang keluaran yang dari PV array dengan algoritma MPPT dengan metode Incremental Conductance.

\subsection{Kontrol arus ramp comparison current control}

Untuk melihat gelombang keluaran dari kontrol arus ramp comparison current control pada PV-Inverter terhubung dengan beban, nilai frekuensi gelombang segitiga diset $1250 \mathrm{Hertz}$ dan nilai amplitude sebesar 15 volt. Nilai Induktor $1 \mathrm{mH}$ dan kapasitor $900 \mathrm{uF}$ pada DC link. Nilai inductor $4 \mathrm{mH}$ dan $4 \mathrm{mH}$, impedansi $0.05 \Omega$ dan $0.05 \Omega$ dan kapasitor $900 \mathrm{uF}$ pada inverter dengan beban $250 \Omega$. Nilai Impedansi $250 \Omega$ dan Induktor $200 \mathrm{mH}$ pada grid. Gambar 21-24 menunjukkan hasil pengujian kontrol arus ini. 


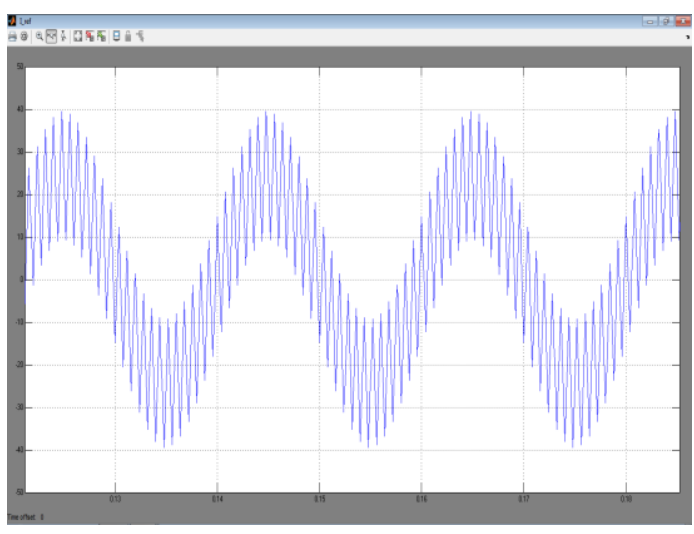

Gambar 21. Bentuk gelombang arus referensi (Iref) yang dibentuk dari hasil penambahan sinyal gelombang sinusoidal dan gelombang segitiga.

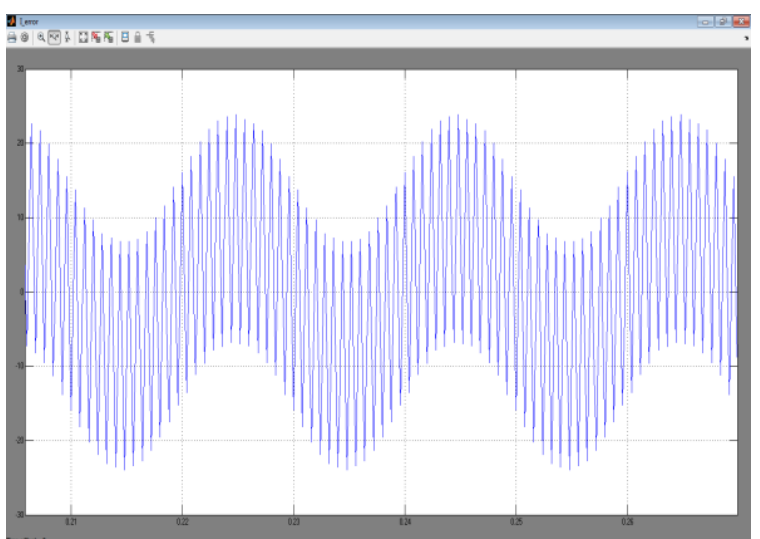

Gambar 22. Bentuk gelombang sinyal arus error (Ierror) yang dibentuk dari hasil penambahan nilai arus referensi dan nilai arus actual

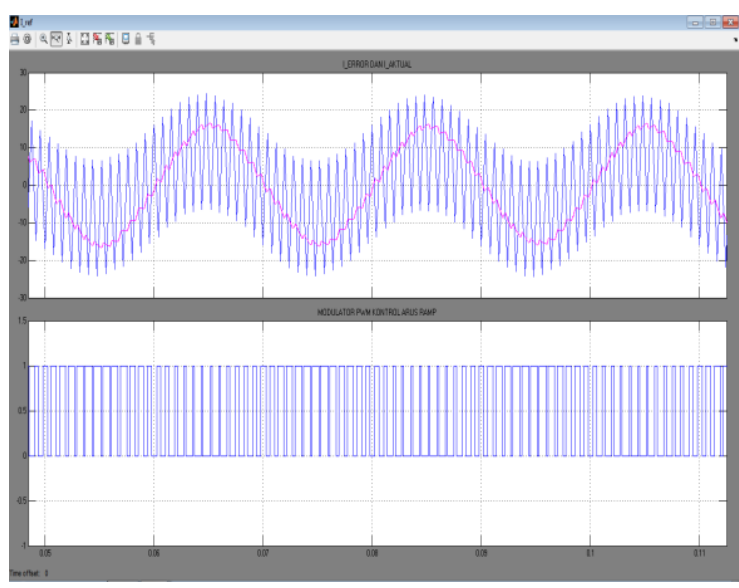

Gambar 23. Sinyal modulator PWM kontrol arus ramp dibentuk dari hasil perbandingan Ierror dengan Iactual

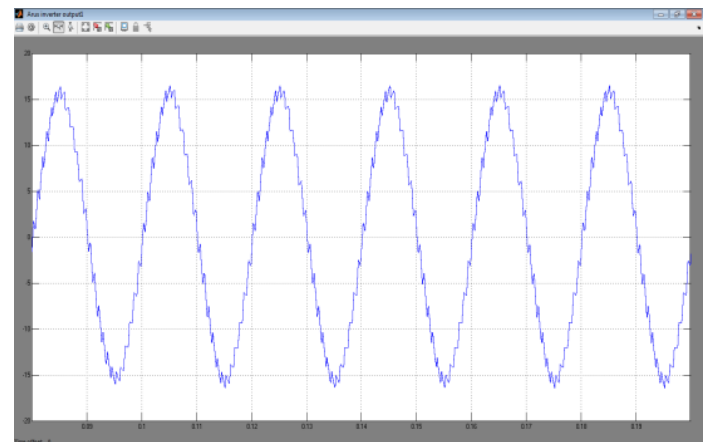

Gambar 24. Bentuk gelombang keluaran arus inverter berupa sinusoidal-segitiga.

\subsection{THD arus output inverter pada PV-} Inverter terhubung dengan grid

Untuk melihat THD arus output inverter pada PV-Inverter terhubung dengan grid, dilakukan dengan memvariasikan frekuensi dan amplitude gelombang segitiga. Hasil pengujian diperlihatkan pada tabel 3 dan tabel 4 .

Tabel 3. THD arus output dengan frekuensi divariasikan dan amplitude tetap 15 volt.

\begin{tabular}{|c|c|c|}
\hline No & Frekuensi switching & THD \\
\hline 1 & $1250 \mathrm{~Hz}$ & $7.25 \%$ \\
\hline 2 & $2500 \mathrm{~Hz}$ & $6.46 \%$ \\
\hline 3 & $3700 \mathrm{~Hz}$ & $4,17 \%$ \\
\hline 4 & $4950 \mathrm{~Hz}$ & $4,10 \%$ \\
\hline
\end{tabular}

Tabel 4. THD arus output dengan amplitudo divariasikan pada frekuensi gelombang segitiga.

\begin{tabular}{|c|c|c|c|}
\hline \multirow{2}{*}{ No } & \multirow{2}{*}{$\begin{array}{c}\text { Frekuensi } \\
\text { switching }\end{array}$} & $\begin{array}{c}\text { THD } \\
\text { amplitudo } \\
\end{array}$ & $\begin{array}{c}\text { 15 volt } \\
\text { amplitudo } \\
\text { 20 volt }\end{array}$ \\
\hline 1 & $1250 \mathrm{~Hz}$ & $7.25 \%$ & $7.25 \%$ \\
\hline 2 & $2500 \mathrm{~Hz}$ & $6.46 \%$ & $6.85 \%$ \\
\hline 3 & $3700 \mathrm{~Hz}$ & $4,17 \%$ & $4,51 \%$ \\
\hline 4 & $4950 \mathrm{~Hz}$ & $4,10 \%$ & $4,31 \%$ \\
\hline
\end{tabular}

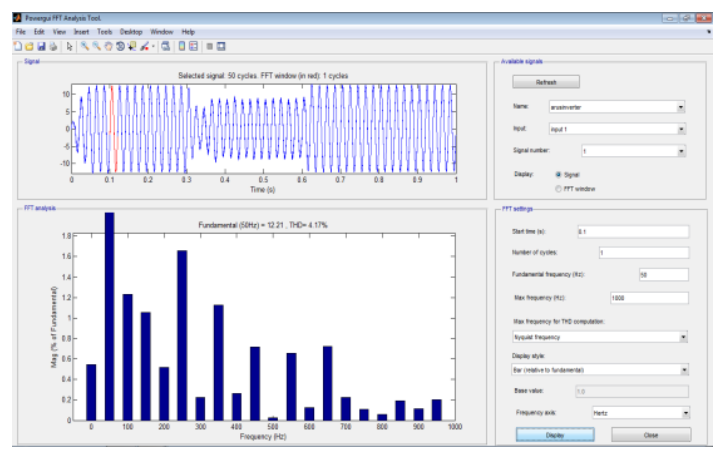

Gambar 25. Dengan fs $3700 \mathrm{~Hz}$, hasil THD diperoleh adalah $4,17 \%$ 


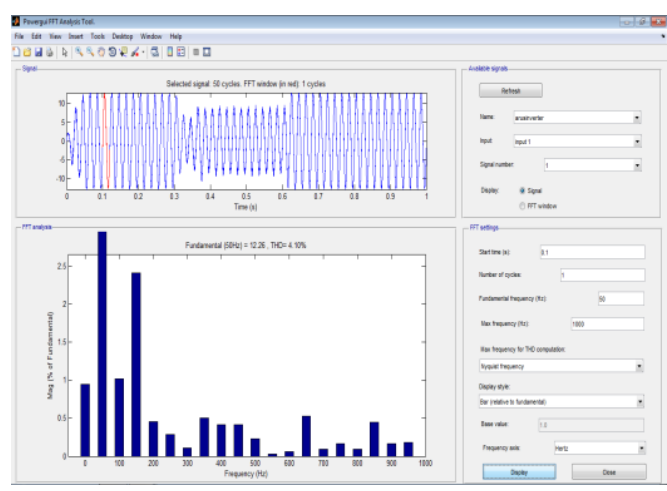

Gambar 26. Dengan fs $4950 \mathrm{~Hz}$, hasil THD diperoleh adalah $4.10 \%$

Dari hasil pengujian tabel 3, terlihat bahwa semakin besar frekuensi gelombang segitiga, kualitas THD semakin baik. Sementara itu dari tabel 4, diketahui bahwa semakin tinggi amplitudo gelombang segitiga, maka kualitas THD semakin buruk.

\section{KESIMPULAN}

Dari hasil simulasi dan analisa penerapan kontrol arus ramp comparison current control, khususnya menyangkut frekuensi dan amplitudo gelombang segitiga sebagai pembentuk modulasi sistem kontrol, dapat disimpulkan bahwa semakin besar frekuensi gelombang segitiga yang diterapkan, maka kualitas arus yang dihasilkan semakin baik (rendah distorsi). Demikian pula, semakin tinggi amplitudo gelombang segitiga semakin buruk kualitas daya arus output yang diperoleh.

\section{DAFTAR PUSTAKA}

[1] Aryuanto Soetedjo, Abraham Lomi, Yusuf Ismail Nakhoda," Pemodelan Sistem Pembangkit Listrik Hibrid Angin dan Surya," Jurusan Teknik Elektro, Fakultas Teknologi Industri, Institut Teknologi Nasional (ITN) Malang.

[2] Tumiran,"Skenario Kebijakan Energy Nasional Menuju Tahun 2050," Dewan Energi Nasional 2012.

[3] PT. PLN (Persero). 2014. Statistik PLN 2013. ISSN 0852-8179 No: 02601-140722.

[4] Alief Rakhman (2013),"Jenis Sistem PLTS,"

http://rakhman.net/2013/04/jenis-sistemplts.html
[5] Mochammad Salman, Mochamad Ashari, Heri Suryoatmojo," Perancangan Inverter Satu Fasa Yang Terhubung Dengan Jaring Distribusi Menggunakan Metode Hysterisis Current Control," Jurusan Teknik Elektro, Fakultas Teknologi Industri, Institut Teknologi Sepuluh Nopember Kampus ITS, Sukolilo Surabaya 6011.

[6] Muh.Imran Hamid dan Makbul Anwari,"Single-Phase PhotovoltaicInverter operation characteristic in Distributed Generation System", http://www.intechopen.com/download/pdf/ 10142

[7] Muh.Imran Hamid, Makbul Anwari, Taufik,"Comparison of current control methods on carrier based VSI-PWM inverter drives from line power quality aspect," TELKOMNIKA Vol 6 No.2, Agustus 2008: 93-100, ISSN:1693-6930.

[8] B.Chitti Babu, B.Vasantha Reddy, K.B.Mohanty,"A Novel Delta Modulator and Modified Ramp Type Current Controller-Two Viable Scheme for Current Controlled Voltage Source Inverter," (C2010 International Journal of Computer Applications (0975 - 8887) Volume 1,No. 3

[9] Firmansyah Putra Pratama, Mochamad Ashari, Heri Suryoatmojo,"Sistem Pembangkit Listrik Hibrida PV-Diesel Microgrid Untuk Daerah Terisolasi Tanpa Menggunakan Media Penyimpan Energi, 'Teknik Elektro, Fakultas Teknologi Industri, Institut Teknologi Sepuluh Nopember (ITS).

[10] Dwiky Alif Satria, Anizar Rizky, Novie Ayub Windarko, Suryono,"Maximum Power Point Tracker(MPPT) untuk Panel Surya Statis Dengan Metode Hill Climbing," Jurusan Teknik Elektronika, Politeknik Elektronika Negeri Surabaya, Institut Teknologi Sepuluh Nopember (ITS) Surabaya.

[11] M.Imran Hamid, Makbul Anwari, Z.Salam and Taufik," Load Sharing Characteristic of Single Phase PV Inverter Connected to Grid," $2^{\text {nd }}$ IEEE International Conference on Power and Energy (PECon 08), December 1 - 3, Johor Bahru, Malaysia.

[12] Atul Gupta, Anurag Porippireddi, Venu Uppuluri Srinivasa, Akash Sharma, Mangesh Kadam,"Comparative Study of 
Single Phase PLL Algorithms for Grid Synchronization Applications," Santerno India Design Center, India. IJECT Vo 1, 3, Issue 4, Oct- Dec 2012.

[13] Zamratul Fuadi, Mochamad Ashari, dan Feby Agung P," Perancangan dan Simulasi Full Bridge Inverter Lima Tingkat dengan Dual Buck Converter Terhubung Jaringan Satu Fasa," Jurnal Teknik POMITS Vol. 3, No. 1, (2014) ISSN: 2337-3539.

[14] M.Archana, Y.C.V.Kondaiah, M.Tech. Scholar, Assistant Professor ,"Grid Interfacing Inverter of Renewable Energy Sources to Improve the Power Quality in Distribution System International," Journal of Advanced Research in Electrical, Electronics and Instrumentation Engineering, Vol.1, Issue 5, November 2012, ISSN: $2278-8875$.

[15] Pierre Giroux (2012)," Grid-Connected PV Array,"

http://www.mathworks.com/matlabcentral/ fileexchange/34752-grid-connected-pvarray

[16] Francisco M. González-Longatt," Model of Photovoltaic Module in Matlab ${ }^{T M}$," 2do Congreso Iberoamericano De Estudiantes De Ingeniería Eléctrica, Electrónica Y Computación (Ii Cibelec 2005).

\section{Biodata Penulis}

Hazlif Nazif, lahir di Padang tanggal 21 Juni 1979 Pendidikan S1 di Jurusan Teknik Elektro Universitas Ekasakti Padang pada tahun 2000. Pendidikan S2 di Jurusan Teknik Elektro Universitas Andalas Padang dengan Program Studi Teknik Energi Elektrik pada tahun 2012. 